\title{
РАДЯНСЬКИЙ ДЖЕНТЛЬМЕН: УКРАЇНСЬКИЙ ПРОФЕСОР СУПРОТИ ВИКЛИКІВ ІСТОРІЇ
}

\section{RADZIECKI GENTELMAN: UKRAIŃSKI PROFESOR W OBLICZU HISTORYCZNYCH WYZWAŃ \\ A SOVIET GENTLEMAN: A UKRAINIAN PROFESSOR IN THE FACE OF HISTORIC TURMOIL}

\author{
Oksana Blashkiv \\ Uniwersytet Przyrodniczo-Humanistyczny w Siedlcach, Siedlce - Polska \\ oksana.blashkiv@uph.edu.pl
}

Ключові слова: українська література, університетский роман, інтелектуал, історія, Юрій Макаров

Słowa kluczowe: literatura ukraińska, powieść uniwersytecka, intelektualista, historia, Yurij Makarow

Keywords: Ukrainian literature, academic novel, intellectual, history, Yury Makarov

Abstract: The article focuses on the presentation of the professor in Ukrainian literature on the basis of Yuri Makarov's novel 3a uверmь десяma (A Quarter to Ten, 2013). The author of the present paper shows it as the academic novel, an emerging genre in contemporary Ukrainian literature. The emphasis is placed on the main character's personal, national and academic identity. A university professor and a linguist, the protagonist constructed his identity through combining the elements of Sovietness, Englishness, and Ukrainianness. While focusing on the protagonist's identity quest, the author also identifies historical context of the novel, which is rooted in Ukrainian socio-historic reality throughout the 1950s-2010s.

Літературознавці відзначають, що за понад чверть століття існування незалежної України ії література майже повністю відійшла від традицій радянської художньої творчості (Поліщук 2015) і набула відкритості та розмаїтості (Чернецький 2015). Ці зміни сприяли народженню „нов[ої] літератур[и], зосереджен[ої] на постаті сучасної людини в актуальних умовах суспільних трансформацій" (Поліщук 2015). Окрім зміни тематики, спостерігалося й розширення спектру літературних жанрів. Серед таких, що ввійшли в українську художню прозу кінця 2000-х років, зустрічаємо і жанр університетського роману (або академічного, за аналогією з англійським терміном the academic novel), зосередженого на образі викладача вищого навчального закладу. Дія таких романів часто виноситься поза межі 
кампусу і стосується різноманітних проблем особистого життя та академічної діяльності професорів, при цьому їхні постаті часто зображені сатирично (Williams 2012: 562). Український варант жанру пропонує картину викладацького життя, вкоріненого у реалії свого місця і часу, що робить його вивчення особливо цікавим та актуальним.

У сучасному літературознавстві дослідження особливостей жанру українського університетського роману ще не почалося, хоча образ інтелектуала та своєрідність його зображення в українській літературі кінця минулого століття були грунтовно розглянуті Марком Андрейчиком у монографії „Інтелектуал як герой української прози 90-х років XX століття". У цій праці літературознавець проаналізував образи персонажів, які належать до когорти „митців, а також тих, зокрема критиків і вчених, хто присвячує своє життя аналізу й інтерпретації творчої діяльності таких осіб" та їх функціонування в тогочасній українській прозі (Андрейчик 2018: 15). Дослідник виділив три типи персонажа української літератури 1990-х років: „хвацький перформансист”, „посол на Захід”, „хвора душа”. Поява перших двох, на думку Марка Андрейчика, була обумовлена станом суспільної ейфорії, викликаного розпадом Радянського Союзу та здобуттям Україною незалежності. Останній тип літературного героя сформувався в період хаосу, котрий наступив після соціальної ейфорії. Усіх цих персонажів, однак, об'єднує почуття співдружності у суспільстві, що активно змінюється. I хоч ці три тенденції ейфорії, хаосу і спільноти проявляються одночасно і тісно взаємопереплітаються, вони скеровані на літературне дослідження „таких питань, як ідентичність, інакшість, моральність" (Андрейчик 170).

У цьому панорамному огляді української інтелектуальної літератури 1990-х років Марк Анрейчик проаналізував, серед інших, образи викладачів вищих навчальних закладів. Літературознавець представляє їх як „посланців на Захід”, оскільки їхнім важливим етичним обов'язком було „відкривати” Захід для України та виконувати функцію посередників між своєю батьківщиною та західним світом (Андрейчик 44). Такими постають герої Володимира Діброви („День народження"), Оксани Забужко („Польові дослідження з українського сексу"). Водночас деякі з цих персонажів наділені рисами героїв „хворої душі” - травмованих та маргіналізованих вчених постколоніальної України. I хоча Марк Андрейчик у своїх роздумах та аналізі не надає їхнім професійним навикам чи університетському статусу особливої ваги, все ж названі вище твори та їхні герої, на наш погляд, органічно вписуються у літературну традицію університетського (академічного) роману. 
Наприкінці 2000-х років (наступного десятиліття після здобуття Україною державної незалежності) українські письменники у своїх романах стали частіше звертатися до образу університетського викладача. Наприклад, герой Ігора Йосипіва - вчений-нефролог, практикуючий лікар-педіатр та викладач одного з медичних університетів Нового Орлеану, герой Анатолія Дністрового - викладач філософії київського вузу (Blashkiv 2018), герой Юрія Макарова - пенсіонер, викладач англійської мови одного з університетів Києва, героїні Дарини Березіної - працівники кафедри англійської філології Миколаӥвського вузу, герой Станіслава Росовецького - співробітник музею, керівник здобувачів наукового ступеня кандидата наук при Львівському університеті (Блашкив 2018). Не менш важливо і те, що автори згаданих творів теж мають викладацький досвід. Як і в англо-американській традиції жанру університетського роману, викладачі-письменники звертаються до тих проблем 3 життя викладачів-науковців, котрі їм достеменно відомі і котрі для них $є$ рубіжними. Одним з таких рубежів стала зміна суспільної ролі інтелектуала у 1990-х роках, а у дещо вужчій перспективі - ролі університетського викладача. На наш погляд, згадані твори зокрема об'єднує тема ідентичності - особистої, національної, академічної. У такому контексті найбілыш показовим є роман Юрія Макарова За чверть десята (2013). Роман увійшов до короткого списку у номінації книга року ВВС-2013. Автор роману - відомий сьогодні журналіст, телеведучий, документаліст та письменник, свого часу - викладач французької мови у Київській консерваторії.

Сюжет роману За чверть десята зосереджений на житті та професійній діяльності викладача вузу, що дозволяє характеризувати твір як університетський роман. Водночас на жаровому рівні твір Юрія Макарова, незважаючи на елементи містики, синтетично поєднує риси літературної автобіографії, сповіді, романів виховання та підведення підсумків. Сповідальний тон оповіді, що ведеться від першої особи однини, стоїть на заваді сатирі, такій очікуваній у випадку англомовного університетського роману. В англо-американських текстах цього жанрового підвиду художній час найчастіше представлений навчальним роком, натомість роман Юрія Макарова, завдяки ретроспективним відступам, охоплює понад шість десятиліть. Тобто, він відображає практично весь життєвий шлях головного персонажа, тоді як фабульний час твору складає заледве тиждень. Історичний час, який постає через призму біографії головного героя, - 1950-2010-ті роки. За цей період країна зазнала значних змін, які неминуче відбилися на долях викладачів університетів - чи не найважливіших ідеологічних установ радянської доби. 
Що ж визначало пріоритети українського викладача та науковця впродовж цього часу? Які виклики історії стали на його шляху до само-пізнання та само-реалізації?

Головний персонаж роману За чверть десята Микола Павлович Бондаренко - звичайний та водночас непересічний викладач англійської мови. Він - радянський джентльмен. Народився герой у 1950-х роках у родині працівників дипломатичних служб радянського посольства у Великобританії. До трьох років разом 3 батьками жив у Лондоні. Це був короткий період, але його було достатньо, щоб невловима інакшість стала частиною його ідентичності, яку оточення Миколи, а врешті і він сам, прийняли як вияв англійськості. Ця риса стала особливо корисною у педагогічній діяльності Миколи Павловича. Він, зокрема, вивчав англійську мову зі студентами через розучування англомовних пісень чи спільного перегляду фільмів в оригіналі 3 наступним їх обговоренням. Бондаренко використовував у співпраці зі студентами нові надбання психології. Наприклад, впроваджував у викладання методи сугестопедагогіки. Яскравість образу викладача, над якою так наполегливо і свідомо працював Микола Павлович, щоб заволодіти увагою студентів, принесла Бондаренкові бажаний результат: 3 роками його популярність серед студентства залишалася незмінно високою. Він „був мало не єдиним, хто розмовляв українською, і [кого] хотілося наслідувати" (Макаров 402). У солідному віці Микола Павлович був подібним на Шона Коннері, а „не на Бонда, професора Джонса-старшого” (Макаров 402). Тобто, виглядав і поводився „як годиться джентльменові”.

Свідоме формування образу англійця Миколи Павловича, як і тисяч радянських читачів, відбувалося на матеріалі англійської літератури кінця XIX століття, зокрема творів Артура Конан-Дойля, тому не дивно, що основними рисами його характеру були стриманість, уважність, чесність та певна легковажність. В англійській культурі впродовж XIX століття (а слідом за нею і серед іноземців) сформувалася думка, що образ джентльмена $є$ втіленням англійськості (Collins 92). Джентельмену були притамані такі основні характеристики: аматорство (amateurism), порядність (sportsmanship), стриманість (self-control). До середини XX століття вважалося, що джентльмен має бути представником вищого або вищо-середнього класу, походити 3 шляхетної родини та отримати добру освіту в Оксбриджі, але всі ці риси були лише пререквізитами до етичних якостей, що складають саму суть „джентльмена”. Що ж до релігії, то вважалося, що джентльменськість - це „повсякденна релігія англійця (lay-religion of the English), і в цьому вона втілювала той моральний код, що був рівноважливим постатям святих в католицьких 
країнах на континенті" (Collins 93). Тому не дивно, що наприкінці XIX століття цим поняттям відзначали „будь-якого чоловіка, який $€$ ввічливим, має хорошу освіту, блискучі манери та вміє поводитися в суспільстві" (Beller M., Leersen 2007: 145). У такому сенсі Микола Павлович був справжнім джентльменом, що жив у реаліях Радянського Союзу.

На відміну від англомовного університетського роману, де сам університет постає як місце інтриг та змагань за місце в ньому (Dalton-Brown 592), український радянський університет, з перспективи Бондаренка-викладача, вимальовується як „ідеологічна установа" - осередок страху, всеохоплюючого контролю та постійних партійних зборів. Якщо тут було місце для боротьби, то лише з собою та своїми моральними принципами. У разі втрати своєї університетської посади (як сталося з колегою Миколи - Романом Вікторовичем) людина просто переставала існувати. Тому звичної для головних героїв „класичних” академічних романів дилеми - залишатися в академії чи покидати це тісне і задушливе середовище - у героя українського університетського роману немає. Його завдання - за відсутності альтернативи - навчитися в цьому середовищі жити. Не знайдемо тут і карикатуризації другорядних персонажів (Dalton-Brown 592): їхні образи скоріше трагічні, хоч це, по-своєму, демонструє „обмеження, що накладаються на інтелект в академічному світі" (Dalton-Brown 2008: 592).

Контроль в університеті у романі Макарова реалізується в рівній мірі щодо ідеології, моралі чи наукової діяльності викладача. У зрілому віці Микола Павлович займається лише викладанням, але свого часу він мав наукові амбіції. Ще в період студентської юності він отримав визнання як поліглот, тому, закономірно, що після закінчення університету герой поступив до аспірантури з мовознавства. Иогго керівником був доктор наук Олексій Юрійович, котрий вважав, що „мовознавство навіть не дозволяє, а передбачає такі широкі паралелі та узагальнення, що в них може знайти заспокоєння будь-який практичний розум” (Макаров 282), і котрому „вдалося навчити учнів на власному прикладі, як можна бути повноцінним у неповноцінному інтелектуальному середовищі" (Макаров 282). Микола Павлович обрав тему власного дослідження відповідно до наукових зацікавленнь керівника: „білінгвізм, диглосія і динаміка взаємовпливу” („Щоправда, на матеріалі Квебеку” (Макаров 286)). В дусі ідеології того часу, сформованої радянською владою, така тема передбачала можливість „вилаяти клятих імперіалістів, що вони занапастили нещасних франкомовних канадщів" (Макаров 286), проте дисертація „вийшла слабенька”, оскільки підпадала радше під 
соціолінгвістику - неіснуючу в радянські часи дисципліну, а її висновки суперечили прийнятій в СРСР ідеології.

Неможливість самореалізуватися в науці була для Миколи Павловича, очевидно, першим випробуванням, поставленим часом та історією. Спроба Миколи Павловича подолати систему закінчилася написанням наукової статті, яка ніколи не була надрукована $з$ огляду на власну безпеку автора та його близьких. 3 ії текстом ознайомився лише один читач - керівник дисертації, котрий, чи не вперше в житті Миколи Павловича, чітко окреслив межі академічної активності та самостійності, можливої в умовах дисциплінарної влади: зацікавлення питанням двомовності (хоч і в Канаді!) молодим кандидатом наук з Києва, наївно запропоноване до друку, потягне за собою політичне розслідування та наслідки, що виходять далеко за межі наукової кар'єри. Саме $з$ цього моменту Микола Павлович почувався повністю безсилим, і це почуття стало частиною його буття та рисою характеру (Макаров 289-290). Щоправда, усвідомлення цього прийшло у віці шістдесяти п'яти років, коли часу на зміни залишилося дуже мало.

Духовна та інтелектуальна стагнація, в яку персонаж Макарова потрапив ще на початку 1980-х, після захисту дисертації з соціолінгвістики, згодом перетворилася на природний стан його існування, що не зник і після розпаду Союзу. Причиною цього було „побоювання радикально поміняти своє життя" (Макаров 122). Проте Микола Павлович був не єдиним витвором системи, він був лише одним із тисяч тих, що жили за лозунгом „Бояться - надо - всего!", і ці тисячі складали „інтелектуальну еліту” країни:

\begin{abstract}
вони (викладачі старшого покоління - О. Б.) не знали, що те їх звичне життя дуже швидко закінчиться, ще якихось десять років, і все почне осипатися, руйнуватися, що невдовзі можна буде не боятися того, чого вони боялися все своє життя, натомість прийде інший страх - страх опинитися зайвим, а вони до цього не готові та й не встигнуть підготуватися. Чого ж вони всі так боялися? Ну, гаразд, не вони. Чого він сам боявся? В ті часи це називалося „неприємності”. Наприклад? Які, власне, могли бути в нього особисто неприємності? Насварять? Якщо замислитися, саме так це й було. Казали: „неприємності по партійній лінії" - евфемізм, зрозумілий абсолютно всім без винятку сучасникам і геть незрозумілий для тих, хто не жив у ті часи й у тій країні. Ось, будь ласка: на партійних зборах членові партії оголосили догану. Що таке збори, що таке догана? (Макаров 135).
\end{abstract}

Слід зазначити, що в науковій літературі відносно мало уваги присвячено мотиву страху (пор. Mnich 113-116) та особливостям його відтворення в сучасній українській літературі. Натомість, цей образ не чужий дослідникам усної історії, котрі означують страх як „особ- 
ливу форму збереження індивідуального травматичного досвіду у колективній пам'яті" (Кузьменко 84). У площині роману За чверть десята страх мати „неприємності по партійній лінії стає перманентною складовою не лише університетського життя, але і рисою характеру головного персонажа, що проявляється у неперервній оцінці своїх рішень через призму чийогось схвалення. Таким чином, Микола Павлович Бондаренко перебуває у стані певного „продовженої юності" чи „замерзлого” підліткового дорослішання, психологічної незрілості.

Розпад Радянського Союзу та економічна криза призвели до зміни суспільних пріоритетів та цінностей. В умовах плинної новочасності, коли ключовими поняттями стають „гнучкість", „змінність", „непевність” (Бауман 11), провідний викладач-англіст Бондаренко не спромігся „перебудуватися": відійти від звичних університетських обов'язків, „Продати” свої вчительські навики і створити власну бізнес-мережу. Від Миколи Павловича це вимагало б зібраності та рішучості, здатності розв'язувати складні ситуації та брати відповідальність за власні рішення. Натомість його надовго захопила розгубленість. Зовсім інакше історичними обставинами скористалася його донька Юля, котра на початку 1990-х років після студентського стажування залишилася у США. Їй, як і багатьом іншим українцям, за професійну реалізацію та кращий рівень життя довелося заплатити еміграцією (Донскіс 259).

Черговим випробуванням для Миколи Павловича став вихід на пенсію. Здавалося б, тепер його життя, спокійне і матеріально забезпечене (власна квартира на Липках, особливо престижному для проживання районі в Києві, достаток), розцвічене регулярними поїздками за кордон, котрі, хоч і оплачувані донькою, все ж засвідчували певний соціально-економічний статус (Береза 9). Проте, „щойно його погнали на пенсію, він розгорнувся вдома: почав брати учнів і час від часу кликав студентів на додаткові заняття - безкоштовно, звісно, заради самоствердження й шліфування методики" (Макаров 31). Праця задля ідеї („,самоствердження й шліфування методики"), як влучно відзначає донька Миколи Павловича, свідчить про „радянську ментальність" часів „підккорення Цілини" (Макаров 21). Відтворення рутини радянського викладача у власній квартирі лише частково заповнює пустку від втрати роботи та смерті двох найважливіших осіб в його житті - матері та дружини. Іншим іï (пустки) компонентом стають дратівливість, запальність, гнівливість, що виникають на тлі розгубленості і неспроможності „побачити” майбутнє (Макаров 20, 405).

Відчуття безсилля та втрати мети у житті свого героя Юрій Макаров підсилює образом магічної сили, якою, що несподівано вия- 
вилось, наділений герой. Як головний герой твору Розповідь лектора Дж. Гайнса (The Lecturer's Tale by James Hynes), палець якого почав підкоряти його волі всіх, кого торкнеться, Микола Павлович зауважує, що його слова, а точніше прокльони, мають чарівну силу: вони здійснюються. У студентські роки Микола Павлович проходив виробничу практику в колгоспі, де зустрів сільську жінку, котра без упину кляла все і всіх та робила це так колоритно, що студенти-етнографи почали вести нотатки ії висловів. Те, що у студентів першого курсу викликало сміх та кпини, для цієї бідолашної жінки було наслідком втрати коханого на війні і неспроможності погодитися 3 цим фактом, тобто формою прояву травми - страхом i безсиллям. Той факт, що Микола Павлович сам не усвідомлює своєї спорідненості з тією жінкою, лише вказує на глибину його особистісної травми, що ії породило безсилля людини перед системою, яке він несвідомо маскував впродовж життя під власною ексцентричністю.

На особливу увагу заслуговує українськість Миколи Павловича. Після повернення родини з Лондона мама Миколи Павловича, яка володіла кількома іноземними мовами, почала працювати у видавництві. Саме відтоді вона розмовляла з сином українською мовою, хоч батько з ним завжди спілкувався російською. Роки по тому він дізнався, що основною причиною повернення в Україну була не стільки зміна керівництва в консульстві Великобританії, де працював батько, скільки єврейське походження матері. Значно пізніше, у 1980-му Микола Павлович написав статтю „Українська мова в Україні: білінгвізм, диглосія чи витискання?" з висновком про те, що українська мова буде продовжувати піддаватися дискримінації у разі відсутності змін громадсько-політичної ситуації в країні (Макаров 298). I хоч на той час це був лише висновок експерта-лінгвіста, читач не міг не побачити у ньому політичну складову. Як зізнається собі Микола Павлович, „українська для нього була ознакою внутрішньої фронди, це правда, але якби він прагнув якоїсь кар'єри, він би спокійно від фронди відмовився, як спокійно колись взяв партквиток. Тобто мова стала самовиправданням за інші компроміси" (Макаров 349). Ще пізніше Микола Павлович вступив у ряди комуністичної партії, проте після розпаду Союзу активної політичної позиції не зайняв, хоч „його кликали до Руху мамині колеги” (Макаров 355). Аж на Майдані у 2004 році,,вперше він себе зі своєю українською відчув остаточно частиною більшості, не екзотом, не фрондером, а представником норми" (Макаров 360), проте і тут він зазнав розчарування: „ці ненажерливі, brought up during rough times... Вони його позбавили надії. Вони йому довели, що його впер- 
те рішення залишатися тут, а не споглядати після обіду Мангеттен з тераси по той бік річки, дурне й хибне" (Макаров 360).

Гнітючий страх визначав життєву траєкторію руху, особистісні та наукові пріоритети, суспільну позицію багатьох сучасників головного персонажа роману $3 a$ чверть десята. На відміну він героїв американських академічних романів, які нерідко зображуються в карикатурно-сатиричному аспекті, персонажі Юрія Макарова, що належать до професорсько-викладацького складу радянських часів, зображені у похмурих тонах. Вони - неспокійні, стурбовані своїми долями, нерідко просто нещасливі, люди. Внутрішнє відчуття неспроможності протистояти соціальним, психологічним перешкодам, породжених „травмами комунізмому”, стало невидимою, але суттєвою рисою характеру не тільки Миколи Павловича, а й, на думку письменника, більшості українських професорів пострадянського періоду. Таким чином, образ Миколи Павловича у певному сенсі втілює концепт „хворої душі", хоча стиль його життя не пов' язаний 3 екстремальними проявами такої недуги (алкоголізмом, наркотичною залежністю чи численними любовними пригодами). Він веде монотонне, пасивне життя на маргінесі суспільства, і спроби замаскувати цей факт приватними уроками зі студентами нічого не змінюють. Цікавим чином це монотонне, пасивне і безвідповідальне існування представників далеко не пасивної освітянської професії перегукується 3 твором Сергія Жадана Iнтернат (2017), головним персонажем якого є вчитель української мови на Донбасі, „що обирає в житті тактику мімікрії, призвичаюючись до обставин, хоча автор усе ж прагне наголосити на його інакшості, хай слабкій, не послідовній чи не проявленій" (Поліщук 2018: 167-168).

Заслуговує на увагу і особисте життя головного персонажа. Микола Павлович - вдівець, котрий заповнює пустку щоденними ритуалами ранішньої пробіжки, підготовки до занять чи переглядом вечірніх телевізійних новин. Стосунки зі значно молодшою жінкою, власною студенткою - несподіванка для нього. Якщо в англомовних романах цього жанру роман викладача зі студенткою переважно маскує його інтелектуальне виснаження, то у творі Макарова він стає поштовхом до остаточних та довгоочікуваних змін. Разом із бажанням спільного майбутнього з Настею Приходько до Миколи Павловича приходить усвідомлення необхідності бути чесним з собою: так, він - „маргінал, базікало і пустоцвіт”, але головне „тримати себе в руках, як годиться джентльменові, якщо вже граєш цю роль усе своє життя, то варто грати послідовно" (Макаров 405). Двадцятип'ятилітня студентка - вільна від страхів та стереотипів радянського минулого; попри свій молодий вік, вона вже багато по- 
дорожувала, знайомилася з іншими культурами, врешті, отримала стипендію на навчання в Університеті Нью-Йорка. У певному сенсі Настя, як і Еліза Дуліттл для Професора Гіггінса, стала Галатеєю Миколи Павловича, проте іï роль значно більша - саме завдяки їй Микола Павлович відважується на нове життя. Власним прикладом Настя - „ця дівчинка живе, як птахи співають” (Макаров 48) - показує герою шлях до гармонії з собою, допомагає перебудувати свої взаємини зі світом.

Важливо також зазначити, що квест ідентичності Миколи Бондаренка підсилюється мотивом подорожі містом. Чи не усі роздуми персонажа відбуваються в дорозі, коли герой їздить у своїй модернізованій внуком-дизайнером старенькій машині („копійочці”) Києвом. Духовні мандри героя реалізуються на знайомій дорозі „дім - робота (університет) - дім". Не менш важливо й те, що всі сорок років Микола Павлович викладав англійську архітекторам і це позначилося на його сприйнятті міста: його дратує, що урбаністичний ландшафт невпинно змінюється на гірше - місто стає непроїзне та негарне. Настя ж - ландшафтний дизайнер, що проектує японські сади для власників приватних будинків під Києвом. Для неї, на відміну від Миколи Павловича, архітектурні зміни не несуть негативної конотації. Для Насті вони - природні і органічні трансформації сучасного міста. Вона - людина свого часу, живе моментом, без далекосяжних планів на майбутнє. I хоч різниця у віці поміж героями велика, відкритий фінал роману залишає можливість успішного розвитку стосунків Миколи Павловича та Насті. На користь цього свідчить і те, що прийняти себе головному персонажеві роману Ю. Макарова таки вдалося.

Підсумовуючи, варто підкреслити, що останне десятиліття запропонувало українським читачам серед інших - жанр університетського роману. Це, вочевидь, стало можливим тому, що минув час і з'явилася можливість подивитися 3 відстані на події, котрі невідворотно вплинули на статус і роль педагогів, викладачів та науковців у суспільстві. Як відомо, з розпадом Радянського Союзу викладач університету, як носій та ретранслятор радянської ідеології, перестав відігравати вагому роль у житті суспільства, а економічна криза, що сильно вдарила по працівниках розумової праці, лише більше їх маргіналізувала. У романі $3 a$ ч८ерть десята Юрій Макаров наближає до читача життєвий досвід філолога-англіста, викладача вузу з сорокарічним стажем, його страхи, втрачені надії та пошуки самого себе і свого місця у спільноті, що швидко змінюється. Слід зазначити, що це новий тип героя, котрий не вписується повністю у класифікацію, запропоновану Марком Андрейчиком, 
що свідчить про подальший розвиток сучасної української літератури та необхідність дослідження особливостей жанру академічного роману.

\section{Бібліографія}

Andrejčik Marko. İntelektual âk geroj ukraïns'koï prozi 90-h rokiv XX stolittia. Per. z angl. İgora Andrušenka. L'vìv: LA „Pìramìda”, 2018. [Андрейчик Марко. Інтелектуал як герой української прози 90-х рокіЪ ХХ століття. Пер. $з$ англ. Ігора Андрушенка. Львів: ЛА „Піраміда", 2018].

Bauman Zig̀munt. Plinnì časi: žittâ v dobu nepevnostì. Per. z angl. Antona Marčins'kogo. Kiïv: Kritika, 2013. [Бауман Зигмунт. Плинні часи: життя в добу непевності. Пер. 3 англ. Антона Марчинського. Київ: Критика, 2013].

Beller Manfred, Leersen Joep (eds.). Imagology: The Cultural Construction and Literary Representation of National Characters. A Critical Survey. Amsterdam-New York: Rodopi, 2007.

Bereza İ. Û. „Vìddzerkalennâ estetičnih potreb ìntelìgenciì v sučasnìj prozì”. Naukovì pracì (Čornomors'kogo deržavnogo universitetu ìmenì Petra Mogili kompleksu "Kiêvo-Mogilâns'ka akademiấ"). Seriâ: Fìlologiâ. Literaturoznavstvo 180/192 (2012): 6-9. [Береза I. Ю. „Віддзеркалення естетичних потреб інтелігенції в сучасній прозі”. Наукові праці (Чорноморського державного університету імені Петра Могили комплексу "Києво-Могилянська академія"). Серія: Філологія. Літературознавство 180 /192 (2012): 6-9].

Berezìna Darina. Fakul'tet. Mikolaïv, 2018. [Березіна Дарина. Факультет. Миколаїв, 2018].

Blashkiv Oksana. "Vagaries of (Academic) Identity in Contemporary Fiction". Journal of Education Culture and Society, 9/1 (2018): 151-160. Web 26.01.2019. <https://jecs.pl/ index.php/jecs/article/view/10.15503jecs20181.151.160>.

Blaškiv Oksana. „Istoričeskie perepetii skvoz' prizmu ukrainskogo universitetskogo romana”. Conversatoria Litteraria XII (2018): 135-149. [Блашкив Оксана. „Исторические перепетии сквозь призму украинского университетского романа". Conversatoria Litteraria XII (2018): 135-149].

Černec'kij Vìtalìj. Literaturì vlastivì peonì sinusoïdnì kolivannâ. [Чернецький Віталій. Лiтературі властиві певні синусоїні коливання]. Web 26.01.2019. <http://litakcent.com /2015/09/15/vitalij-cherneckyjliteraturi-vlastyvi-pevni-synusojidni-kolyvannja/>.

Collins M. "The Fall of the English Gentlemen: the National Character in Decline, c. 1918-1970". Historical Research 75/187 (2002): 90-111. Web 26.01.2019. <http://nbuv. gov.ua/UJRN/Npchdufl_2012_192_180_3>.

Dalton-Brown Sally. "Is There Life Outside of the Genre of the Campus Novel? Academic Struggles to Find a Place in Today's World". The Journal of Popular Culture 41/4 (2008): 591-600.

Dnìstrovij Anatolìj. Drozofila nad tomom Kanta. L'viv: Piramida, 2010. [Дністровий Анатолій. Дрозофіла над томом Канта. Львів: Піраміда, 2010].

Donskìs Leonìdas. Zbentežena identičnist' ì sučasnij svit. Kiïv: Fakt, 2010. [Донскіс Леонідас. Збентежена ідентичність і сучасний світ. Київ: Факт, 2010]. 
Josipìv İgor. Unìversitet. L'vìv: Pìramìda, 2007. [Йосипів Ігор. Університет. Львів: Піраміда, 2007].

Kuz'menko Oksana. Obraz "strahu” âk etnokonstanta fol'klornih narativìv pro ìstoričnìdrami peršoï XX st. In: Social'nì zlami ì povorotnì momenti: makropodï kriz' prizmu avtobiografičnoï rozpovidì (uporâdniki: O. R. Kìs', G. G. Grìnčenko, T. Pastušenko). L'vìv: Ìnstitut narodoznavstva NAN UKRAÏNI, 2014: 83-101. [Кузьменко Оксана. Образ „страху” як етноконстанта фольклорних наративів про історичні драми першої половини XX ст. В: Соціальні злами і поворотні моменти: макроподії крізь призму автобіографрічної розповіді (упорядники: О. Р. Кісь, Г. Г. Грінченко, Т. Пастушенко). Львів: Інститут народознавства НАН України, 2014: 83-101].

Makarov Ûìj. Za čvert' desâta. Kiïv: Nora-Druk, 2013. PDF. [Макаров Юрій. За чверть десята. Київ: Нора-Друк, 2013. PDF].

Mnich Roman. Žanrovaâèvolûciâ èlegii v literature XX veka. Siedlce: IKiBL, 2015. [Mnich Roman. Жанровая эволюиия элегии в литературе XX века. Siedlce: IKiBL, 2015.]

Polîsuk Âroslav. „Reoriêntaciâ v sučasnìjukraïns'kìj lìteraturì”. Sinopsis: tekst, kontekst, media 3/11 (2015). [Полішук Ярослав. „Реорієнтація в сучасній українській літературі". Синопсис: текст, контекст, медіа $3 / 11$ (2015)]. Web 26.01.2019. <http://dx.doi.org/10.28925/2311-259x.2018.\%281\%29>.

Polîsuk Âroslav. Gìbridna topografiâ. Mìscâ $j$ ne-miscâ v sučasnìj ukraïns'kij lìteraturì. Černìvcì: Knigi-XXI, 2018. [Поліщук Ярослав. Гібридна топографія. Місия й не-місияя В сучасній украӥнській літературі. Чернівці: Книги-XXI, 2018].

Rosovec'kij Stanìslav. Pomsta peršodrukarâ. Kiïv: Gamazin, 2009. [Росовецький Станіслав. Помста Периодрукаря. Київ: Гамазин, 2009].

Williams Jeffrey J. "The Rise of the Academic Novel". American Literary History 24/3 (2012): 561-589. 